2003

\title{
What Happened to the Skeptical Environmentalist
}

David Schoenbrod

New York Law School, david.schoenbrod@nyls.edu

Christi Wilson

Follow this and additional works at: https://digitalcommons.nyls.edu/fac_articles_chapters

Part of the Environmental Law Commons

\section{Recommended Citation}

New York Law School Law Review, Vol. 46, Issues 3 \& 4 (2002-2003), pp. 581-614

This Article is brought to you for free and open access by the Faculty Scholarship at DigitalCommons@NYLS. It has been accepted for inclusion in Articles \& Chapters by an authorized administrator of DigitalCommons@NYLS. 


\title{
WHAT HAPPENED TO THE SKEPTICAL ENVIRONMENTALIST ${ }^{1}$
}

\author{
David S. Schoenbrod ${ }^{2}$ And Christi WILSON $^{3}$
}

\section{The Skeptical EnVironmentalist}

Bjorn Lomborg was raised in a bastion of environmental protection, Denmark, by parents who work in the earth and taught him to protect it. As a young man he was a Greenpeace activist. Now, at the age of thirty-six, his involvement with Greenpeace has ended, but his concern for living things remains. He is a vegetarian. His counter-culturalism also remains. He attires himself in jeans and a tee shirt to address groups of be-suited business leaders.

Although nurtured as an environmentalist, Bjorn Lomborg was trained as a skeptic. At the University of Aarhus in Denmark, he is a professor of statistics, a discipline that scrutinizes assertions by systematically comparing them to data.

Lomborg's environmentalism and skepticism came into alignment in February of 1997. While leafing through Wired Magazine he happened upon an interview with the American economist, Julian Simon. Simon asserted that statistics belie the popular idea that the environment is going to ruin. As Lomborg wrote of his reaction:

I was provoked ... I always tell my students how statistics is one of science's best ways to check out whether our venerable social beliefs stand up to scrutiny or turn out to be myths. Yet, I had never questioned my own belief in an ever deteriorating environment - and here was Simon, telling me to put my beliefs under the statistical microscope.

In the fall of 1997 I held a study group with ten of my sharpest students, where we tried to examine Simon thor-

1. Copyright 2002, David Schoenbrod and Christi Wilson. We thank Sidney Cone, Randolph Jonakait, William Mills and Ross Sandler for their generous guidance and assistance.

2. David Schoenbrod is a Professor of Law at New York Law School in New York, New York. Yale, B.A. 1963, LL.B. 1968; Oxford University, B.Phil. 1965.

3. Christi Wilson is a student (Class of 2003) at New York Law School located in New York, New York. 
oughly. Honestly, we expected to show that most of Simon's talk was simple, American right-wing propaganda. And yes, not everything he said was correct, but contrary to our expectations, it turned out that a surprisingly large amount of his points stood up to scrutiny. ${ }^{4}$

Lomborg's work with his students turned into a series of articles in a Danish newspaper, ${ }^{5}$ then a book in Danish, and now a book in English published by Cambridge University Press entitled The Skeptical Environmentalist: Measuring the Real State of the World. It begins by describing what schools, colleges, newspapers, and television teach us about the environment. ${ }^{6}$ Typical is the statement from an Oxford University Press book for children that " $[t]$ he balance of nature is delicate but essential for life. Humans have upset that balance, stripping the land of its green cover, choking the air, and poisoning the seas." 7

The Skeptical Environmentalist goes on to compare such standard fare with what the statistics show. Some examples:

- While we are told that air pollution is killing us, air quality in major cities in developed countries is actually much cleaner than it was fifty or a hundred years ago. ${ }^{8}$ London's air is cleaner than it was fifty years ago, a hundred years ago, or even four hundred years ago. ${ }^{9}$

- While we are told that the human population is surging ever upwards to a point that guarantees mass starvation, world population growth is slowing so markedly that population will level off by $2200 .^{10}$

- While we are told that the forests are being decimated by acid rain, the authoritative study of acid rain showed it did little if any damage to trees in North America. ${ }^{11}$

- While we are told that pesticides and pollution are causing an epidemic of cancer, they cause at most a trivially small portion of all

4. Bjorn Lomborc, The Skeptical Environmentalist xix (Cambridge University Press 2001) (1998).

5. Id. at xix.

6. Id. at $3-32$.

7. $\quad I d$. at 3 .

8. Id. at 177 ("In the US, the total number of car miles traveled has more than doubled over the past 30 years. The economy has likewise more than doubled, and the population has increased by more than a third. Nevertheless, over the same period emissions have decreased by a third and concentrations much more.").

9. Id. at 164 .

10. LOMBORG, supra note 4 , at 47.

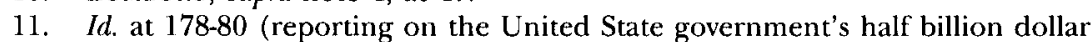
National Acid Precipitation Assessment Program; similar results have been reported for Europe). 
cancers. ${ }^{12}$ If pollution and pesticides have any perceptible impact on cancer rates in the United States, it is trivially small compared to that resulting from eating too much fat and not enough fruits and vegetables. ${ }^{13}$ (Those who find it hard to accept this conclusion may be reassured to know that the same conclusion was also reached by Justice Stephen Breyer after a systematic review of the science literature. ${ }^{14}$ )

Lomborg does acknowledge ongoing environmental problems such as global warming and species extinction, but argues that environmentalists grossly exaggerate them. ${ }^{15}$ One prominent scientist asserted that the earth would soon lose 50 percent of her known species. ${ }^{16}$ Hearing such a statistic makes one fear that we will have nothing left but battery chickens and white bread, but Lomborg points out that the best estimate of species loss is 0.7 percent over the next 50 years. ${ }^{17}$ Losing fifty percent would be, Lomborg points out, "a catastrophe by any standard. However, losing 0.7 percent . . . is not a catastrophe, but a problem-one of many that mankind still needs to solve." 18

The distinction between a catastrophe and a problem is critical. A looming catastrophe impels us to do everything we can to avert it. A problem does not loom. It presents us with choices about its priority relative to other problems.

Global warming illustrates the point. If it is a looming catastrophe, we must do everything we can to slow it down and, in particular, ratify the Kyoto global warming treaty immediately, as environmental organizations urge. Lomborg sees global warming as a problem. The United Nations' Intergovernmental Panel on Climate Change (IPCC) presents six main scenarios for emissions of global warming gases under which it projects the climate will warm from 2-4.5 degrees centigrade by 2100. ${ }^{19}$ Lomborg raises doubts about how the IPCC projects temperature increases from emission increases but he lays those doubts aside when he questions its assumptions about the emissions of gases that impact the temperature of the earth. ${ }^{20} \mathrm{He}$ argues that the IPCC overestimates emissions of global warming gases because it ignores that

12. Id. at 229 (EPA estimates that pollution contributes to $1-3 \%$ of US environmentally caused cancers).

13. Id. at 229-30.

14. Stephen Breyer, Breaking the Vicious Circle: toward effective risk reguLATION (Harvard University Press 1993).

15. LomBorc, supra note 4, 249-322.

16. Id. at 249.

17. Id. at 255.

18. Id. at 257.

19. Id. at 264 .

20. LOMBorg, supra note 4 , at 278-87. 
prices for energy sources other than fossil fuels, such as solar and wind generated energy, have been falling quickly and will make them increasingly competitive with fossil fuels. ${ }^{21}$ In particular, he cites a study concluding that, if these falling prices are taken into account, we are apt to have a warming of less than 2 degrees centigrade by 2100 and cooling thereafter. ${ }^{22}$

Lomborg then goes on to argue that even if the IPCC projections are accurate ${ }^{23}$ and government does nothing about global warming, the warming would cause disruptions, but, in Lomborg's words, it "will not decrease food production, it will probably not increase storminess or the frequency of hurricanes, it will not increase the impact of malaria or indeed cause more deaths." ${ }^{44}$ Kyoto would delay warming by only six years even if all the signatories do what they promise. ${ }^{25}$ It is, of course, meant to be only a first step, but it comes at a considerable cost. The studies cited by Lomborg conclude it will cost "at least $\$ 150$ billion dollars a year and probably much more." 26 Lomborg argues that there are better ways to spend the money. ${ }^{27} \mathrm{He}$ points out, for example, that the cost of Kyoto for one year alone would eliminate the unsanitary drinking water that now kills 2 million people per year and causes half a billion people to become seriously ill each year. ${ }^{28}$ UNICEF estimates that $\$ 70-80$ billion a year, half the cost of Kyoto, "could give all Third World inhabitants access to all the basics like health, education, water, and sanitation."29

Whether Lomborg rightly characterizes the studies of global warming and its antidotes, he is surely right to insist that we get straight whether environmental issues are catastrophes or problems.

Lomborg argues that we keep hearing environmental activists present problems as looming environmental catastrophes because they have left the truth behind in order to advance their favored policy agendas. ${ }^{30}$ Even if they do, business interests skew scenarios their own way. Unfortunately, prominent media organizations often end up presenting the story only the environmentalists' way-as if that is the truth revealed by science. Take the environmental cancer issue for example. Mainstream scientists believe that pollution is not an important

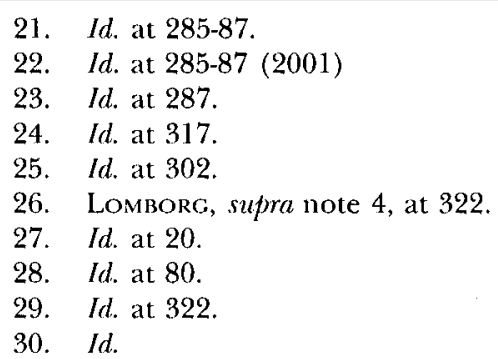


cause of cancer, but the press tells the public that it is. This disparity spawned a book, Environmental Cancer-A Political Disease? ${ }^{21}$ Its authors polled mainstream cancer researchers, who disagreed sharply with the position of environmental advocates that pollution is a major cause of cancer. The cancer researchers also viewed the press as overstating the risk from pollution, food additives, and pesticides. In other words, the newspapers and networks erroneously present the views of the environmental advocates as mainstream science. Asked who is credible on questions of environmental cancer, the researchers gave the highest grades to the National Cancer Institute and a scientist who holds that environmental cancer is vastly exaggerated and among the lowest ratings went to the Tobacco Institute, environmental advocacy organizations, TV networks, and the New York Times. ${ }^{32}$ To the cancer researchers, the Tobacco Institute is incredible because it minimizes the dangers of smoking and the press is incredible because it exaggerates the dangers of pollution. "Cancer scare" makes a better headline than "no cancer scare" and journalists are sympathetic to the environmental advocates' political agenda. ${ }^{33}$

\section{The Reaction to The SKePtical ENVIRONMENTaLIST}

The environmental movement was bound to react with a vengeance to Lomborg. He accused prominent environmental scientists and activists by name of brewing up phony catastrophes to get their way. His challenge could not be dismissed as the self-interested protestations of industrial corporations, nor could it be disdained as lightweight drivel. The book is documented with its 2,930 footnotes and published by Cambridge University Press. Nor could it be ignored because it was being prominently covered around the world. A review in the Washington Post called the book "a magnificent achievement" and "the most significant work on the environment since . . . Silent Spring." 34 The New York Times praised it as "a substantial work of analy-

31. S. Robert Lichter \& Stanley Rothman, Environmental Cancer - A PolitiCAL Disease? (Yale University Press 1999).

32. Id. at 161-62, 167.

33. Polling data on file with authors.

34. Denis Duton, Greener Than you Think, Washington Post, Oct. 21, 2001 at BWo1. 
sis." 35 The Economist published a favorable review, gave Lomborg space on its pages, and wrote a laudatory editorial. ${ }^{36}$

The counter-attack came hot. The most prestigious of the natural science journals, Nature, ran a review that compared Lomborg to "those who ... argue that gay men aren't dying of AIDS, that Jews weren't singled out by the Nazis for extermination, and so on." 37 Scientific American similarly sought to read Lomborg out of the scientific community. Its January, 2002 issue ran a scathing editorial and four equally scathing commentaries by scientists allied with the environmental cause. ${ }^{38}$ Under the caption "Science defends itself against the Skeptical Environmentalist," the magazine, accused Lomborg of getting the facts wrong. The charges included "misunderstanding of the underlying science," 39 "numerous errors and infelicities," 40 and that "his mistakes include apparent misreadings or misunderstandings of statistical data," 41 and "the text itself is rife with careless mistakes." $42 \mathrm{Al}-$ though Lomborg asked the magazine to give him an opportunity to defend himself in that issue, the magazine's editor-in-chief, John Rennie, turned him down. Although there was time enough to include a reply from Lomborg in the January issue, Rennie decided to postpone Lomborg's reply until May and even then limited it to one-eighth the length of the attack. ${ }^{43}$ Rennie later explained that Lomborg had already received so much press that "we felt it would not be a terrible disservice" to delay his reply. ${ }^{44}$ Lomborg's recourse was to put Scientific

35. Nicholas Wade, Scientist at Work/Bjorn Lomborg; From an Unlikely Quarter, EcoOplimism, N.Y. Tıмes, Aug. 7, 2001, at F1.

36. The Truth about the Environment, Economist, Aug. 4, 2001; Energetic Visionaries, Economist, Sept. 1, 2001; Doomsday Postponed, Economist, Sept. 8, 2001.

37. Stuart Pimm \& Jeff Harvey, No Need to Worry About the Future, Nature, November 2001 , at 149 .

38. John Rennie, Misleading Math about the Earth, Scientific American, Jan. 2002, at 62; Stephen Schneider, Global Warming; Neglecting the Complexities, Scientific AmeriCAN, Jan. 2002, at 63; John P. Holdren, Energy: Asking the Wrong Question, Scientific American, Jan. 2002, at 65; John Bongaarts, Population: Ignoring its Impact, Scientific American, Jan. 2002, at 67; Thomas Lovejoy, Biodiversity: Dismissing Scientific Process, SclENTIFIC AMERICAN, Jan. 2002, at 69.

39. Rennie, supra note 38 , at 61 .

40. Holdren, supra note 38 , at 67 .

41. Id. at 66 .

42. Lovejoy, supra note 38 , at 71 .

43. The SA reply was $6300+/$ - words compared to the 800 words that Lomborg was allowed. (On file with authors)

44. Keay Davidson, Optimistic researcher draws pessimistic reviews, SAN Francisco Chronicle, Mar, 4, 2002, at A4. 
American's attack on his website along with a paragraph by paragraph response. The magazine threatened to sue Lomborg for copyright infringement unless he removed its attack. Lomborg suggested that the magazine place the attack and his response on its website, but Scientific American did not do so. Lomborg removed his response and posted the following notation: "Unfortunately, Scientific American has threatened legal action if I did not remove the text of their critique . . . Patrick Moore, co-founder of Greenpeace, has actually put out my original text on his website." 45 As one observer appropriately commented, "Evidently, Scientific American is not interested in dialogue and peer review of its own work." ${ }^{46}$ Only several months later, once it had crafted its reply to Lomborg's response did the magazine post Lomborg's response.

Leading scientists have gone beyond attacking Lomborg. Some prominent scientists threatened to boycott Cambridge University Press if it did not drop the book. Another called upon the head of Cambridge University Press to fire the editor responsible for publishing it.

During a debate at an Oxford University bookstore, Lomborg's opponent, Mark Lynas, an environmental scientist and activist, threw a pie in Lomborg's face. ${ }^{47}$ The magazine of the Natural Resources Defense Council, a leading American environmental organization, wrote approvingly that, "[f]or Lynas, The Skeptical Environmentalist was a diversion from important research-and a real cream puff." 48

The scientific community's reaction was not, however, monolithic. Washington's former editor of Nature wrote a letter to the journal criticizing it for publishing its vitriolic attack on Lomborg. ${ }^{49}$ The Italian version of Scientific American magazine published a favorable review; noting that "Lomborg mercilessly exposed tricks or faults that enabled a growing number of scientists and politicians to state that the world is on the edge of the precipice."50 That, however, was before the Ameri-

45. See http://www.greenspirit.com/lomborg (last visited Oct. 15, 2002).

46. Ron Bailey, Green With Ideology, Reason Magazine, May 1, 2002, available at WL 5725199.

47. David Thomas, Anti-Christ of the Green Religion Bjorn Lomborg. . ., THE SUnday TelegraPh, Jan. 20, 2002, at 21.

48. Jonathan Cook, The Trouble with Bjom, ON EARTH, March 22, 2002, at 10.

49. See Stephen Budiansky, Letter to the Editor, NATure, Jan. 24, 2002 at 364.

50. Gilberto Corbellini, The Skeptical Arrived From the Green, Le Scienze 399, Nov. 2001 (translated by Gianfranco Bangone). 
can version published its attack, which the Italian version dutifully published. 51

\section{The Nature of the Lomborg Debate}

To get to the substance of the criticism of Lomborg, we decided to list and categorize each criticism leveled in the most prominent journals, Scientific American, Nature, and Science. We found the attacks on Lomborg fell into four categories:

1. Personal attacks: Personal attacks on Lomborg and others not going to the substance of the book's argument that the environmental movement exaggerates environmental problems.

2. Supposed errors of fact: Charges that the book got facts wrong.

3. Supposed strawman arguments: Charges that the book attacks assertions that responsible scientists in the environmental movement no longer espouse (such as that acid rain was decimating the forests).

4. Framing the facts inappropriately: Charges that the book characterizes agreed upon facts in ways his critics find inappropriate to policy making.

The resulting list, which is reproduced in full in the appendix, yields some interesting results.

The first category-personal attacks-has a surprisingly large number of entries given that science is supposed to be a search for truth. Some of the attacks (e.g., Lomborg is not an expert ${ }^{52}$ ) are in the nature of pulling rank rather than dealing with the accuracy of his analysis. Other attacks are irrelevant to the accuracy of his factual assertions and are simply wrong. It is asserted, for example, that he is against government action to protect the environment, but he repeatedly states he is for it, but wants it to be based on facts rather than myths. ${ }^{59}$

The second category-supposed errors of fact-has a surprisingly small number of entries. ${ }^{54}$ Scientific American backs up its generalized

51. See Le Scienze, Feb. 2002, available at www.lescienze.it (last visited Nov. 5, 2002).

52. See Schneider, supra note 38 , at 62.

53. See infra text pp. 583-85.

54. Lomborg has kept track of his errors. To see the small number of errors you need only $\log$ on to his website. The list of erratum on his website is scrupulous, complete, and very short. None of the errors come anywhere near suggesting bad faith or sloppy methods. http://www.lomborg.com (last visited Aug. 16, 2002). 
assertions that science must be defended from someone ignorant of the facts with very few specifics. Key facts found by Lomborg are actually not challenged at all. ${ }^{55}$ For example, the attack does not challenge Lomborg's assertion of $0.7 \%$ species loss over the next 50 years and in its reply to his response admits that "that is roughly the figure that most environmental biologists currently tend to favor."56 Scientific American does not back up its charge by challenging any of his major factual conclusions about the state of the earth, such as that air quality is getting much better. As detailed in the appendix, the magazine makes only eleven specific allegations of factual error and it is wrong on all but two of them. One is that Lomborg wrote "catalyzing" when he should have written "electrolyzing" and the other is that he wrote nuclear energy constitutes twenty percent of energy production in the countries that have nuclear power when he should have written that it constitutes twenty percent of electricity production. These errors are not of a nature that throw into question the validity of his ultimate factual conclusions and/or his good faith. They are simply minor mistakes to be expected in any book that covers such a wide range of technical topics. The reason the book is largely free of factual errors on the ultimate factual conclusions is that Lomborg draws his conclusions from the very sources regularly cited by environmentalists, such as the United States Environmental Protection Agency (EPA), the Food and Agricultural Organization, and the International Panel on Climate Change. ${ }^{57}$ The review in Science credits Lomborg with getting the facts right: "I find his analysis of the ... contention [that the environment is getting better] compelling." 58

The third category-supposed strawman arguments-has a few entries. It is true that some (but not all) of the assertions about the state of the earth that Lomborg attacks are not presently supported by

55. A leading earth scientist, Michael Grubb, reviewing Lomborg's book in the serious scientific journal, Science, credits Lomborg with getting the environmental facts right. "Lomborg has compiled an immense amount of data to support his fundamental assertion that in many respects the environment is getting better rather than worse.... I find his analysis of [this] contention compelling . . . ." Grubb goes on to dispute Lomborg's policy conclusions, or what Lomborg argues are Grubb's misreadings of his policy conclusions. Michael Grubb, Relying on Manna from Heaven?, Science, November 2001 , at $1285-86$.

56. John Rennie, A Response to Lomborg's Rebullal, Scientific American, Apr. 15, 2002.

57. See http://www.greenspirit.com/lomborg (last visited Oct. 15, 2002).

58. Grubb, supra note 55, at 1285 . 
eminent scientists. ${ }^{59}$ Some of these assertions were once supported by such scientists, but have been dropped. Others of these assertions are the inventions of fringe scientists. Yet, Lomborg, however, has a good and consistent reason for attacking all the assertions he targets in this book, whether presently supported by eminent scientists or not-the environmental movement and the media repeat them as scientific fact and the public is taken in by them. His eminent scientific critics understandably resent having their work targeted along with assertions that they no longer make or never have made, but they themselves are to blame. They have largely held their tongues when the public hears pseudo science rolled out in favor of environmental regulation. If they were to show a tenth the energy that they expended in calling Lomborg unscientific on instead correcting the sloppy pro-environmental science in the press, Lomborg would have had no occasion to write the book in the first place.

The fourth and final category of criticism-framing the facts inappropriately-is the most numerous. For one example, Scientific American took Lomborg to task for emphasizing the estimate that 0.7 percent of the world's species will be lost over the next fifty years. ${ }^{60}$ The problem with this estimate is not that it lacks a sound scientific foundation, but that it tends to minimize the species loss issue because the public has heard far higher estimates of extinction rates. Scientific American would prefer to maximize the species loss issue by comparing the expected species loss with the far lower rate of extinction rate that would prevail if man were not on the earth. Scientific American claims that Lomborg is behaving "cynically" 61 for characterizing this fact his way and not their way. Rennie writes in his response to Lomborg's rebuttal: "[a] public that knows the action would cut the extinction rate from 1,000 times the background level to only 500 times could find reasonable motivation to act. A public hearing that extinction rates would drop from 0.7 percent per fifty years to .35 percent might wonder why it should bother." ${ }^{2}$

This is an argument about whether the glass is half empty or half full. Lomborg characterizes the facts in ways favorable to his policy preferences while his critics want him to characterize the data in ways favorable to theirs. There would be nothing wrong with Lomborg's

59. Holdren, supra note 38 , at 65.

60. Lovejoy, supra note 38 , at 70 .

61. Id.

62. Rennie, supra note 56. 
critics explaining why, in their opinion, he frames the facts inappropriately. They go beyond that, however, to claim the exclusive right to speak for science.

\section{Law And the Lomborg Debate}

The law is relevant to the debate over The Skeptical Environmentalist. Disputes about public policy and how to characterize facts relevant to settling such disputes are, of course, the standard stuff of courtroom advocacy. It is thus one upon which the law can shed some light.

The debate over The Skeptical Environmentalist is relevant to modern environmental law. It is largely a creature of statues, regulations, and treaties. They are shaped to a considerable extent by the public's understanding of environmental issues. Should Lomborg succeed in changing the public perception of environmental issues, he will have a profound impact on environmental law around the world.

If we think of the making of modern environmental law as a grand legal proceeding in which Lomborg and his opponents seek to participate as expert witnesses, Lomborg's critics seek to have him disqualified as an expert witness. Their efforts to discredit Lomborg can be evaluated by considering how their arguments to disqualify Lomborg would fare under the law of evidence.

In proceeding in this way, we are adapting a technique used by Annette Gordon-Reed in evaluating the way in which white historians discredited the African American witnesses' assertions that Thomas Jefferson fathered Sally Hemmings' children. ${ }^{63}$ Professor Gordon-Reed asked, in essence, how a careful judge would react to the various arguments that the African Americans were wrong. ${ }^{64}$ We ask how a careful judge would react to the arguments that Lomborg should be disqualified as an expert witness.

Lomborg's critics assert that he should be disqualified because he is not "an expert as regards environmental problems" 65 in that he is a statistician, not an earth scientist. Under the rules of evidence,

if scientific, technical, or other specialized knowledge will assist the trier of fact to understand the evidence or to determine a fact in issue, a witness qualified as an expert

63. Annette Gordon Reed, Thomas Jefferson and Sally Hemmincs: An AmeriCAN CONTROVERSY (The University Press of Virginia 2000) (1997).

64. Id.

65. Schneider, supra note 38 , at 62 . 
by knowledge, skill, experience, training, or education, may testify thereto in the form of an opinion or otherwise, if (1) the testimony is based upon sufficient facts or data, (2) the testimony is the product of reliable principles and methods, and (3) the witness has applied the principles and methods reliably to the facts of the case. ${ }^{66}$

The fact at issue here is the state of the earth. Assessing it requires not only data about particular plants, animals, and ecological systems, but also the use of statistics to meld such particularized information into meaningful conclusions. In doing that job, Lomborg' can qualify as an expert. First, he is relying on recognized facts, as evidenced by the failure of his critics to identify significant mistakes of fact in his work. Second, he is applying reliable principles and methods, those of the discipline of statistics. Third, he is applying those principles and methods in a reliable way. The nub of the argument against Lomborg is not that he errs in his application of statistical principles and methods, but rather that he frames the results of his analysis inappropriately.

Lomborg's critics also contend that he should be disqualified because "most of his nearly 3,000 citations are to secondary literature and media articles." 67 Lomborg's citations to media articles are appropriate to the purpose for which he uses them, to show the message on environmental quality that the public is receiving. To evaluate the actual state of the earth, Lomborg relies on secondary as well as primary scientific literature. That is, however, not a problem. The law of evidence holds that "an expert opinion may be based on any type of evidence commonly used by experts in the field." ${ }^{8}$ Scientific experts, including Lomborg's staunch critics, rely on secondary sources. ${ }^{69}$ Primary sources are generally about narrow issues, such as the impact of a given type of acid rain on a given kind of tree. Coming to a conclusion about the impact of all kinds of acid rain on trees generally requires bringing together many such primary sources. Reaching a conclusion about the

66. USCS Fed Rules Evid. R. 702 (2002).

67. Schneider, supra note 38, at 63; see also Pimm \& Harvey, supra note 37, at 149.

68. American Technology Resources v. US, 893 F.2d 651 (3rd Cir. 1990).

69. For example, Stuart Pimm, co-author of the NATURE review recently published a book in which over half the citations are to non-peer reviewed sources. STUART $\mathbf{L}$. Pimm, The World According to Pimm: A Scientist Audits the Earth (McGraw-Hill Professional 2001). Similarly, Stephen Schneider, who in his attack in Scienrific AmeriCAN on Lomborg's global warming chapter, criticizes him for relying on secondary sources, writes that the author of the secondary source on global warming upon which Lomborg most heavily relies, the Intergovernmental Panel on Climate Change, is "the most credible international assessment body." Schneider, supra note 38. 
state of the earth in a single book necessarily requires reliance on secondary sources.

Finally, some of Lomborg's critics argue that he is not worth listening to because he has come up with no new information. ${ }^{70}$ This, however, helps to qualify Lomborg as an expert. "If the facts or data are of a type reasonably relied upon by experts in the particular field of expertise, then the expert is permitted to use this information as a basis for [his] opinion."71 Scientists use other scientists' data as a basis for their own studies. It is simply not a problem that Lomborg relies on other people's data.

The attack on Lomborg's unscientific credentials is disingenuous. The fight is really over who should have control of environmental policy.

\section{How Matters Stand Now}

The attack against Lomborg has failed on many fronts. In February of 2002, the government of Denmark, appointed Bjorn Lomborg to head a newly created Institute for Environmental Evaluation. ${ }^{72}$ It is to function as a monitoring agency separate from that country's environmental regulatory agency. ${ }^{73}$ We will undoubtedly hear more from Professor Lomborg in the future.

The effort to get Cambridge University Press to withdraw the Lomborg book and fire the editor responsible never came off, and without any boycott. In fact, Cambridge has sold over 60,000 copies of the book, thanks in part to the viciousness of the attack on Lomborg.

Nonetheless, it would be wrong to dismiss the viciousness of the attack against Lomborg as harmless. It has scared editors not only at Cambridge but also at other leading academic presses. Fear of being subject to such an attack is likely to affect decisions to publish books at the margin and many such publication decisions are made at the margin.

More important than the impact on the presses is the impact on environmental scientists themselves. Environmental scientists depend heavily on government grants. Those who run government funding

70. See Stephen H. Schneider, Hostile Climate On Bjorn Lomborg and Climate Change, GRIST MACAZINE, Dec. 12, 2001, available at http://www.gristmagazine.com/grist/ books/scneider/121201.asp (last visited Nov. 5, 2002).

71. Stephen A. Saltzburg et al., Federal Rules of Evidence Manual $\$ 703.02[2]$ (8th ed. 2001).

72. Howls from Creens, Economist, Mar. 2, 2002.

73. Id. 
agencies get larger budgets by showing that the problems they address are important. That in turn produces pressure on researchers to produce results that help grow their funding source's budget. The result is a series of subtle pressures that can produce an orthodoxy of the sort challenged by Lomborg. The viciousness of the attack on him suggests that scientists who characterize their research results in a way contrary to that orthodoxy stand in danger of losing their funding. 
APPENDIX

This appendix lists the specific criticisms of The Skeptical Environmentalist alleged in the initial attacks in Scientific American, Nature, and Science. We describe the critics' allegations and then append our own comment to the allegation. We also place each criticism into a category (personal attack, framing the facts inappropriately, no longer espoused, and supposed fact error).

John Rennie, Misleading Math about the Earth, SCIENTIfic AmErican, Jan. 2002.

Although Rennie's statement is highly critical, it contains no specifics.

Stephen Schneider, Global Warming; Neglecting the Complexities, Scientific American, Jan. 2002.

\section{Personal Attack}

Allegation: Lomborg "admits, 'I am not myself an expert as regards environmental problems.'"74

Comment: Schneider pulled this sentence from a passage where Lomborg notes that he had the various chapters reviewed by experts in various environmental fields. ${ }^{75}$

\section{Personal Attack}

Allegation: Lomborg does not, for the most part, use peer-reviewed sources. "[M] ost of his nearly 3,000 citations are to secondary literature and media articles."76

Comment: Lomborg uses the media articles mainly to document what the public hears. In Schneider's field, the secondary scientific source Lomborg relies upon most heavily is the Intergovernmental Panel on Climate Change. Schneider himself relies upon its work heavily. ${ }^{77}$

\section{Framing the Facts Inappropriately}

Allegation: Lomborg talks about various scenarios for global warming as "plausible," but does not define that term. He uses the word "plausible' often, but curiously for a statistician, he never attaches any probability to what is "plausible."78

74. Schneider, supra note 38 , at 62 .

75. See http://www.greenspirit.com/lomborg (last visited Oct. 15, 2002).

76. Schneider, supra note 38 , at 63.

77. See http://www.greenspirit.com/lomborg (last visited Oct. 15, 2002).

78. Schneider, supra note 38 , at 63. 
Comment: Lomborg responds that it would be spurious to give a mathematical definition to "plausible" when it is impossible to be mathematically precise about the exact probability of various outcomes. ${ }^{79}$

\section{Framing the Facts Inappropriately}

Allegation: "Although the IPCC gives a wide range for most of its projections, Lomborg generally dismisses these ranges, focusing on the least serious outcomes." 80

Comment: Lomborg does discuss the range of projections and the more serious outcomes. ${ }^{81}$

\section{Framing the Facts Inappropriately}

Allegation: In his global warming scenarios Lomborg does not even offer "one probability . . . for the chance of a dangerous outcome." 82 Comment: Lomborg does discuss the probabilities of two major dangerous outcomes, the sliding of the West Antarctic Ice Sheet (WAIS) and the shut-down of the thermohaline circulation (THC) that drives the Gulf Stream. ${ }^{83}$ In fact, John Rennie in Scientific American's April $9^{\text {th }}$ issue acknowledges that Schneider is "mistaken when Schneider accused Lomborg of not including any probability estimates for dangerous outcomes." 84

\section{Supposed Fact Error}

Allegation: " $[\mathrm{H}]$ e makes a firm assertion that climate 'will certainly' not go beyond 2 degrees $\mathrm{C}$ warming in the $22^{\text {nd }}$ century - a conclusion at variance with the IPCC, other natural climate assessments, and recent studies in the field of climate science. ${ }^{85}$

Comment: Schneider misquotes Lomborg. ${ }^{86}$

Framing the Facts Inappropriately

Allegation: To minimize concerns about global warming, Lomborg paraphrased his discussion of a 1989 Hadley Center paper in Nature in a 1997 article in Science without noting that the original paper contains

79. See http://www.greenspirit.com/lomborg (last visited Oct. 15, 2002).

80. Stephen Schneider, Global Warming; Neglecting the Complexities, Scientific AmerICAN, Jan. 2002, at 63.

81. LOMBORG, supra note 4, at 264, 288.

82. Schneider, supra note 38 , at 63 .

83. See http://www.greenspirit.com/lomborg (last visited Oct. 15, 2002).

84. Rennie, supra note 56 .

85. Schneider, supra note 38 , at 63 .

86. LомвоRG, supra note 4 , at 286. 
a caveat that its projections are not necessarily more accurate than standard projections of global warming. ${ }^{87}$

Comment: Lomborg argues that he ought to be able to rely on an article in Science and, in any event, since 1989, new evidence the alternative projection is more accurate. ${ }^{88}$

\section{Framing the Facts Inappropriately}

Allegation: Similarly, Lomborg cites Richard S. Lindzen's controversial stabilizing feedback theory "as evidence that the IPCC climate sensitivity range should be reduced by a factor of almost three. He fails either to understand this mechanism or to tell us that it is based on only a few years of data in a small part of one ocean. Extrapolating this small sample of data to the entire globe is like extrapolating the strong destabilizing feedback over midcontinental landmasses as snow melts during the spring." 89

Comment: Lindzen himself, in a letter to Scientific American, states "What Schneider really demonstrates is that he completely misunderstands what [he and his co-authors] have done" and that all Lomborg did was "devote a quarter of a page to our paper in order to point out that it 'might pose a challenge' to the IPCC range."90

\section{Framing the Facts Inappropriately}

Allegation: Lomborg relies on a Danish researcher's controversial hypothesis as an alternative to the increase in carbon dioxide as an explanation for global warming. ${ }^{91}$

Comment: Lomborg points out that "neither the Danish cloud physicists nor [he] sa[id] that [the hypothesis is] an alternative" to global warming, merely a "supplementary explanation." Lomborg acknowledges that this supplemental theory has "unsolved scientific problems," but also may have substantial explanatory force. ${ }^{92}$

\section{Framing the Facts Inappropriately}

Allegation: Lomborg wishfully portrays rosy scenarios for renewable resources replacing fossil fuels as an energy source. ${ }^{93}$

\footnotetext{
87. Schneider, supra note 38 , at 63 .

88. See http://www.greenspirit.com/lomborg (last visited Oct. 15, 2002).

89. Schneider, supra note 38 , at 63 .

90. Richard S. Lindzen, Letters to the Editor, Scientific American, May 2002.

91. Schneider, supra note 38 , at 63 .

92. See http://www.greenspirit.com/lomborg (last visited Oct. 15, 2002).

93. Schneider, supra note 38 , at 63 .
} 
Comment: Schneider ignores the peer-reviewed evidence adduced by Lomborg that the price of renewable energy sources is falling at a rate that will make them sufficiently economically competitive to justify his supposedly wishful thinking. ${ }^{94}$

\section{Framing the Facts Inappropriately}

Allegation: Though Lomborg criticizes the governments that removed the cost-benefit studies from the IPCC's Working Group II's final report. "Lomborg says "A political decision stopped IPCC from looking at the total cost-benefit or global warming.' "95

Comment: Lomborg responds that "two different arguments are being confused." He acknowledges that he criticizes the deletion from the Working Group II report of cost-benefit analyses showing that global warming would produce a net gain for develop countries and a net loss for developing countries. The "a political decision" statement was in regard to another report, that of Working Group III (WGIII) ${ }^{96}$

\section{Framing the Facts Inappropriately}

Allegation: Cost benefit studies were downgraded for a reason. "[T] hese studies fail to consider so many categories of damages held to be important by political leaders. A total analysis would have to include the value of species lost, crucial ecosystem services degraded, inequity created by the poor being hurt more than the rich, and likely changes to climatic extremes and variability." 97

Comment: Lomborg responds that it would have made more sense to supplement the cost-benefit analysis. ${ }^{98}$

\section{Framing the Facts Inappropriately}

Allegation: Lomborg has cited only one figure $-\$ 5$ trillion - for climate damages instead of pointing out the range of possible damages in the literature. Lomborg's failure to give a range of numbers for climate damages is inconsistent with his giving "a range for climate policy costs [the costs of implementing the Kyoto Protocol.]."99

Comment: Lomborg notes that he used a mean estimate and that this estimate is comparable to that in the most recent IPCC report to provide estimates of climate Lomborg contends that he had to give a

94. See http://www.greenspirit.com/lomborg (last visited Oct. 15, 2002).

95. Schneider, supra note 38 , at 64 .

96. See http://www.greenspirit.com/lomborg (last visited Oct. 15, 2002).

97. Schneider, supra note 38 , at 64 .

98. See http://www.greenspirit.com/lomborg (last visited Oct. 15, 2002).

99. Schneider, supra note 38 , at 64 . 
range of "climate policy costs," because there are many alternative ways of implementing the Kyoto Protocol. ${ }^{100}$

\section{Framing the Facts Inappropriately}

Allegation: In estimating "climate policy costs," Lomborg relies on the work of economists rather than engineers. ${ }^{101}$

Comments: Lomborg does talk about the arguments of engineers and also notes that the engineering estimates fail to consider the indirect impacts of regulatory initiatives on production. ${ }^{102}$

\section{Framing the Facts Inappropriately}

Allegation: Lomborg treats Kyoto as the sole response to global warming while its advocates see it as a first and necessary step for dealing with global warming. ${ }^{103}$

Comments: Lomborg argues that Kyoto will do very little about global warming and that little will come at a disproportionate cost and taking the additional steps Schneider advocates is a worse deal. ${ }^{104}$

\section{Personal Attack}

Allegation: Lomborg's message is "everything-will-turn-out-fine."105

Comment: Lomborg's book calls for action on a number of environmental issues, but is against Kyoto. ${ }^{106}$

\section{Personal Attack}

Allegation: "The publisher would have been wise to ask natural scientists as well as social scientists to review the manuscript, which was published by the social science side of the house . . . that the natural scientists weren't asked is a serious omission for a respectable publisher such as Cambridge University Press." 107

Comment: According to the Cambridge University Press editor in charge of the book, "the referees were all senior figures and came from leading departments on both sides of the Atlantic. Two referees were from environmental science departments, one, from climate science and one from a social science department. To my surprise all recommended publication. One reader was actively hostile to the pro-

100. See http://www.greenspirit.com/lomborg (last visited Oct. 15, 2002).

101. Schneider, supra note 38 , at $64-5$.

102. LOMBORG, supra note 4 , at 312-13.

103. Schneider, supra note 38 , at 64 .

104. See http://www.greenspirit.com/lomborg (last visited Oct. 15, 2002).

105. Schneider, supra note 38, at 65.

106. LomborG, supra note 4, at 258-333.

107. Schneider, supra note 38 , at 65 . 
ject but nonetheless recommended publication, partly because he felt that it was useful for books such as this to be published every now and then." 108

John P. Holdren, Energy: Asking the Wrong Question, SCIEnTIFIC

AMERICAN, Jan. 2002.

\section{No Longer Espoused}

Allegation: Lomborg points to an old argument (we are running out of energy) that we no longer make. We now say we are running out of environment. ${ }^{109}$

Comment: In other words, Holdren agrees with Lomborg that we are not running out of energy. Holdren disagrees with the book's main contention - that we are not running out of environment - without providing any specifics. ${ }^{110}$

\section{Framing the Facts Inappropriately}

Allegation: Those with whom Lomborg actually takes issue with are pundits who argue that we are running out of cheap oil, not oil. ${ }^{111}$

Comment: Lomborg asks whether the pundits and analysts are "reasonable people to challenge?" Plus, as Lomborg points out, running out of oil is running out of cheap oil: If you want to find out whether oil is getting more scarce then you have to look at whether oil is getting more expensive. ${ }^{112}$

\section{Framing the Facts Inappropriately}

Allegation: Lomborg is correct that oil's dominance in the world market will not end because its reserves are depleted. Rather its dominance will end because other energy resources will become more. attractive. But, Lomborg does not acknowledge the idea that transferring from oil to other resources may not be so smooth. ${ }^{113}$

Comment: Lomborg argues that history is full of prophecies of coming death, but we have found ways to meet the need. ${ }^{114}$

\footnotetext{
108. Email from Chris Harrison to David Schoenbrod, July 18, 2002 (on file with authors).

109. Holdren, supra note 38 , at 65 .

110. See http://www.greenspirit.com/lomborg (last visited Oct. 15, 2002).

111. Holdren, supra note 38 , at 65 .

112. See http://www.greenspirit.com/lomborg (last visited Oct. 15, 2002).

113. Holdren, supra note 38 , at 66 .

114. See http://www.greenspirit.com/lomborg (last visited Oct. 15, 2002).
} 


\section{Framing the Facts Inappropriately}

Allegation: Does not define "proved resources" and "remaining ultimately recoverable resources." 115

Comment: Although Lomborg does pause to state formal definitions, he does plainly distinguish these concepts. ${ }^{16}$. It is hard imagine readers with the patience and interest to make their way through Lomborg's tome who would not grasp this concept by the time they are done if they did not already grasp it before they are done.

\section{Framing the Facts Inappropriately}

Allegation: Lomborg does not discuss how problems in the Middle East could affect oil availability. ${ }^{117}$

Comment: Again, it is hard to imagine readers who do not grasp this point.

\section{Framing the Facts Inappropriately}

Allegation: Lomborg assures us that there will be enough coal for us to use for the next 1,500 years but does not tell us how much coal per year we can use in order to make it last 1,500 years. ${ }^{118}$

Comment: In discussing reserves in any particular year, Lomborg measures years of reserves in terms of consumption in that year. ${ }^{119} \mathrm{Al}$ though he is not always explicit on this point, it is again hard to imagine readers who would be mislead on this point.

Allegation: Lomborg claims that the "vast part" of coal's sulfur dioxide and nitrogen dioxide emissions have been reduced in developed countries, but in fact there have been only "moderate reductions" from 1980 to $1998 .{ }^{120}$

Comment: Lomborg is correct and Holdren is misleading. Holdren uses 1980 as the base year, but there were large reductions in emissions before then. Holdren also uses data on total emissions, while Lomborg, as Holdren must surely know, was talking about emissions per unit of energy because his point is that we have the potential to make coal cleaner. ${ }^{121}$ Given the increase in coal usage, the data Hol-

115. Holdren, supra note 38 , at 66 .

116. LOMBORG, supra note 4 , at 125 .

117. Holdren, supra note 38 , at 66 .

118. Id.

119. LOMBORG, supra note 4, at 127.

120. Holdren, supra note 38 , at $66-7$.

121. See http://www.greenspirit.com/lomborg (last visited Oct. 15, 2002). 
dren cites obscures the drop since 1980 in the emissions per unit of coal used.

\section{Supposed Fact Error}

Allegation: Figure that nuclear energy constitutes $20 \%$ in countries that have nuclear power is wrong. ${ }^{122}$

Comment: Lomborg did err. He acknowledges that he should have written: " $20 \%$ of the electricity generation from nuclear power."123 This error was not, however, material to any of Lomborg's conclusions.

\section{Framing the Facts Inappropriately}

Allegation: Lomborg "barely notes in passing that breeder reactors "produce large amounts of plutonium that can be used for nuclear weapons production." "124

Comment: Lomborg devotes three paragraphs to nuclear power. Within that context, he devotes a sentence to the weapons risks of the fast breeder reactor. ${ }^{125}$ A reader would get the impression that Lomborg believes this risk should be taken seriously.

\section{Framing the Facts Inappropriately}

Allegation: Lomborg "persistently presents numbers to two and threefigure precision for quantities that cannot be known to such accuracy." A good example of this is the 43 percent figure that Lomborg uses to illustrate how much "American energy use is wasted." 126

Comment: Lomborg's response: "Of course, there are a lot of numbers that we do not know well, but the general idea in statistics is that if these numbers have been generated by a process described by evenly distributed errors, the more precise number is still the best predictor of the real number - or to put it more clearly: If studies have shown that 43 percent of all American energy use is wasted, the real number may very well be $38-48$ percent, but had I rounded this figure down to 40 or up to 45 , it would have been worth less - and Holdren could then have criticized me for conveying muddled results . . . [m]oreover, the 43 percent is actually described right off one of the best-selling college environmental books." 127

122. Holdren, supra note 38 , at 67.

123. See http://www.greenspirit.com/lomborg (last visited Oct. 15, 2002).

124. Holdren, supra note 38 , at 67.

125. LoмBorG, supra note 4, at 272.

126. Holdren, supra note 38 , at 67 .

127. See http://www.greenspirit.com/lomborg (last visited Oct. 15, 2002). 


\section{Framing the Facts Inappropriately}

Allegation: "He makes claims, based on a single citation and without elaboration, that are far from representative of the literature," citing Lomborg's claim that it is possible to produce safe cars getting more than 120-240 miles per gallon. ${ }^{128}$

Comment: Lomborg retorts that Holdren fails to provide citations to the literature upon which he relies. ${ }^{129}$

\section{Supposed Fact Error}

Allegation: He wrote electrolyzing when he meant catalyzing. ${ }^{130}$

Comment: Lomborg erred, although he points out that he had the correct word in the Danish version of his book and the error came in the translation. ${ }^{131}$ This error, too, is immaterial.

\section{Supposed Fact Error}

Allegation: Lomborg wrongly maintains that "grid-connected wind power requires 'a sizeable excess capacity' in the windmills because these alone 'need to be able to meet peak demand.'"132

Comment: Holdren is quoting Lomborg out of context. In the passage quoted, Lomborg was discussing the feasibility of an all-renewable energy strategy. In that context, he points out that the need for excess wind capacity depends upon what other energy sources are connected to the grid. It is hard to imagine readers who would not understand that hooking generators fueled by non-renewable sources to the grid would reduce the need for excess capacity. ${ }^{133}$

John Bongaarts, Population: Ignoring its Impact, ScIENTIFIC AMEriCAN, . Jan. 2002.

\section{Supposed Fact Error}

Allegation: "Lomborg's view, regarding the population problem, that the 'the number of people is not the problem' is simply wrong."134

Comment: Bongaarts does not try to say why this is wrong and neglects to point out what Lomborg says the problem is: Poverty, not people, is the problem. ${ }^{135}$

\footnotetext{
128. Holdren, supra note 38 , at 67 .

129. See http://www.greenspirit.com/lomborg (last visited Oct. 15, 2002).

130. Holdren, supra note 38 , at 67.

131. See http://www.greenspirit.com/lomborg (last visited Oct. 15, 2002).

132. Holdren, supra note 38 , at 67 .

133. LOMBORG, supra note 4 , at 34 .

134. Bongaarts, supra note 38 , at 67 .

135. See http://www.greenspirit.com/lomborg (last visited Oct. 15, 2002).
} 


\section{Framing the Facts Inappropriately}

Allegation: Lomborg selectively uses statistics giving "the impression that the population problem is largely behind us. The global population growth rate has indeed declined slowly, but absolute growth remains close to the very high levels observed in recent decades." 136

Comment: Lomborg does say that absolute growth remains close to the top. ${ }^{137} \mathrm{~A}$ recent report by the United Nations Population Division concludes that during this century "a slowing of population growth rates" can be expected, and this will be followed by "slow reductions in the size of the world population." 138

\section{Framing the Facts Inappropriately}

Allegation: Lomborg's discussion on global population trends is misleading because it does not take account of "the enormous contrast among world regions," specifically mentioning the contrast between developed and developing regions. ${ }^{139}$

Comment: Lomborg presents data for both developed and developing countries throughout the book. ${ }^{140}$ Arguably, however, he should have placed more emphasis on regional rather than global trends.

\section{Framing the Facts Inappropriately}

Allegation: Lomborg fails to note that the population increase in the developing world will be just as great in 2000-2025 as it had been in the prior quarter century. ${ }^{141}$

Comment: Yes, but Bongaarts is obscuring the fact that such absolute population growth was trending higher in the first period and trending lower in the second. ${ }^{142}$

\section{Framing the Facts Inappropriately}

Allegation: Lomborg's density calculation regarding how much land is available for each person is misleading because it considers the ratio of

136. Bongaarts, supra note 38 , at 67 .

137. LOMBORG, supra note 4 , at 47 .

138. Ben J. Wattenberg, Overpopulation Turns Out to Be Overhyped, WALL STREET JourNal, March 4, 2002, at A14 (Wattenberg stated family planning and environmental problems "should be viewed calmly and without panic." Wattenberg should be careful; Lomborg's book carried the same message and has been highly criticized for it).

139. Bongaarts, supra note 38 , at 67 .

140. See generally, LomborG, supra note 4.

141. Bongaarts, supra note 38 , at 67 .

142. See http://www.greenspirit.com/lomborg (last visited Oct. 15, 2002). 
all people to all land instead of people to "land that remains after excluding areas unsuited for human habitation or agriculture."143

Comment: Lomborg would have done better to attend to this point. In Bongaart's next paragraph, he does acknowledge the potential to increase food production globally. ${ }^{144}$ The mismatch between where the people will be and where the food can be produced might be dealt with by the people migrating and food being shipped, but not without problems. Lomborg would have produced a better book if it dealt more with regional as opposed to global problems, but his decision not to do so is understandable, the resulting book might not have been portable.

\section{Framing the Facts Inappropriately}

Allegation: Lomborg is wrong to argue that declining crop prices suggest no coming food shortage because government subsidies have helped to keep prices low. ${ }^{145}$

Comment: Lomborg points out that more efficient production and better crops have helped to keep prices low, and that all leading food analysis institutions predict still lower prices. ${ }^{146}$

\section{Framing the Facts Inappropriately}

Allegation: Feeding a growing population will require "turning the earth into a human feedlot." "Lomborg does not deny this environmental impact but asks unhelpfully, "what alternative do we have?" "147 Comment: Lomborg points out that we now use about $11 \%$ of the global land surface area for agriculture. He cites data suggesting that in 2030 we will feed 8 billion much better using $12 \%$ of the global land area. This is, he writes, hardly "turning the earth into a giant human feedlot." 148

\section{Framing the Facts Inappropriately}

Allegation: "Lomborg correctly notes that poverty is the main cause of hunger and malnutrition, but he neglects the contribution of population growth to poverty." 149

\footnotetext{
143. Bongaarts, supra note 38 , at 68 .

144. Id.

145. Id.

146. See http://www.greenspirit.com/lomborg (last visited Oct. 15, 2002).

147. Bongaarts, supra note 38 , at $68-9$.

148. See http://www.greenspirit.com/lomborg (last visited Oct. 15, 2002).

149. Bongaarts, supra note 38 , at 69 .
} 
Comment: Lomborg's argument is that high reproduction is partly a result of poverty so that the best way to reduce population growth is to reduce poverty. ${ }^{150}$

\section{Framing the Facts Inappropriately}

Allegation: Lomborg discusses migration from rural to urban areas as a welcome development but the migrant flow is so large that the absorptive capacity of cities is overwhelmed with the result that "the traditional urban advantage is eroding in the poorest countries, and the health conditions in slums are often as adverse as in rural areas." 151

Comment: Lomborg argues that it is misleading to compare the worst city areas (slums) with the average rural areas. ${ }^{152}$

\section{Framing the Facts Inappropriately}

Allegation: Life has improved "but Lomborg does not acknowledge that this favorable trend has been brought about in part by intensive efforts by governments and the international community. . . Unfortunately, the unrelenting we-are-doing-fine tone that pervades Lomborg's book encourages complacency rather than urgency." 153

Comment: This is a cheap shot. Lomborg does call for more aid to developing countries. ${ }^{154}$

Thomas Lovejoy, Biodiversity: Dismissing Scientific Process, ScIEnTIFIC AMERICAN, Jan. 2002.

\section{Framing the Facts Inappropriately}

Allegation: Lomborg asks whether Biodiversity is important and "discounts its value" in less than a page. ${ }^{155}$

Comment: This point is polemical. It is entirely appropriate to question the premises of policy arguments. In any event, after arguing that some of the points made in favor of biodiversity are overblown, Lomborg nonetheless concludes that it is important. ${ }^{156}$

150. See http://www.greenspirit.com/lomborg (last visited Oct. 15, 2002).

151. Bongaarts, supra note 38 , at 69 .

152. See http://www.greenspirit.com/lomborg (last visited Oct. 15, 2002).

153. Bongaarts, supra note 38 , at 69 .

154. See generally, LOMBORG, supra note 4.

155. Lovejoy, supra note 38, at 69.

156. See http://www.greenspirit.com/lomborg (last visited Oct. 15, 2002). 


\section{Supposed Fact Error}

Allegation: Lomborg confuses "the process by which a species is judged to be extinct with the estimates and projections of extinction rates."157 Comment: Lomborg recognizes this distinction in his book. ${ }^{158}$

\section{Framing the Facts Inappropriately}

Allegation: "Projections of extinction rates . . . are generally based on the long-term established relationship between species number and area." Lomborg argues this method of projecting species loss is contradicted by data from the Brazilian rain forest whose area was cut by 90 percent, but where there has been no observed loss of extinctions. This is, however, no contradiction at all because the species loss may have been lagged or went unnoticed because of a dearth of biologists in Brazil. ${ }^{159}$

Comment: Lomborg responds that the theory upon which Lovejoy relies projects a 50 percent species loss, but there was no observed species loss in either animals or plants. Lomborg notes that the IUCN (World Conservation Union) "found this evidence quite disturbing to the species-area relationship." 160

\section{Supposed Fact Error}

Allegation: "In presenting an analysis for Puerto Rico, Lomborg again cites apparently contradictory evidence that although 99 percent of the primary forest was lost, the island ended up with more birds than it supported before deforestation. First of all, total forest cover was never so drastically reduced. More significantly he ignores that seven of the 60 species unique to Puerto Rico were lost." "He completely misses the point that the world's bird fauna was reduced by seven species." 161

Comment: Lomborg got the 99 percent figure from a Department of Agriculture study. Lomborg's book states that "seven out of 60 species of birds had become extinct." 162

\section{Framing the Facts Inappropriately}

Allegation: Lomborg inappropriately discusses species loss in terms of percentages rather than "multiples of the normal extinction rates, which is preferable in that it is not necessary to assume a figure for the

157. Lovejoy, supra note 38 , at 69 .

158. LOMBORG, supra note 4 , at 219-57.

159. Lovejoy, supra note 38 , at $69-70$.

160. See http://www.greenspirit.com/lomborg (last visited Oct. 15, 2002).

161. Lovejoy, supra note 38 , at 70 .

162. LOMBORG, supra note 4 , at 254. 
total number of species on earth." "He fails to recognize the altered approach as an improvement in the science." 163

Comment: Lomborg responds that it is preferable for policy discussion to be framed in terms of percentage rates because non-biologists have no sense of the normal extinction rate. ${ }^{164}$

\section{Personal Attack}

Allegation: In the chapter on acid rain "the research is so shallow that almost no citation to peer-reviewed literature appears." 165

Comment: As pointed out in the body of the article, Lomborg's critics cite secondary sources themselves. ${ }^{166}$

\section{Supposed Fact Error:}

Allegation: "Lomborg asserts that big-city pollution has nothing to do with acid rain, when it is a fact that nitrogen compounds (Nox) from traffic are a major source" of pollution. ${ }^{167}$

Comment: Lomborg's point is that acid rain is not a major contributor to pollution concentrations in big cities and therefore not the health hazard it was made out to be. ${ }^{168}$ Lovejoy misstates Lomborg to say that big cities do not contribute to acid rain.

\section{Framing the Facts Inappropriately}

Allegation: His discussion of a study showing acid rain had no effect on three tree species fails to note that none of the species include conifers, such as red spruce, which are particularly sensitive. He also does not mention the impact of acid rain on nutrients in the soil. ${ }^{169}$

Comment: Valid points.

\section{Framing the Facts Inappropriately}

Allegation: Lomborg "confounds tree damage from air pollution 30 to 60 years ago with subsequent acid rain damage and makes an Alice-inWonderland statement that the only reason we worry about foliage loss is "because we have started monitoring this loss." "170

Comment: Lomborg responds "this seems disingenuous because all I do is to point out that research shows that foliage loss was equally high

\footnotetext{
163. Lovejoy, supra note 38 , at 70 .

164. See http://www.greenspirit.com/lomborg (last visited Oct. 15, 2002).

165. Lovejoy, supra note 38 , at 70 .

166. See http://www.greenspirit.com/lomborg (last visited Oct. 15, 2002).

167. Lovejoy, supra note 38 , at 70 .

168. Lомвокс, supra note 4 , at 178.

169. Lovejoy, supra note 38 , at 70.

170. Lovejoy, supra note 38 , at 70 .
} 
30-60 years ago as today. This is also why the alleged Alice-in-Wonderland statement might not be so outrageous."171

Framing the Facts Inappropriately

Allegation: "It is simply untrue that 'there is no case of forest decline in which acidic deposition is known to be a predominant cause.' Two clear-cut examples are red spruce in the Adirondacks and sugar maples in Pennsylvania." 172

Comment: The quoted language to which Lovejoy objects is from a report from the National Acid Precipitation Assessment Program. ${ }^{173}$

\section{Framing the Facts Inappropriately}

Allegation: Lomborg's chapter on forests suffers from "superficial research and selective use of numbers" because Lomborg uses an FAO report that "any statistician should know . . . could not be used for a valid time series." 174

Comment: Lomborg's book pointed out the poor quality of this data, but observed that it was the only data available. ${ }^{175}$

\section{Framing the Facts Inappropriately}

Allegation: Lomborg uses misleading numbers regarding the massive fire in Indonesia in 1997, making it sound as if the forest area lost was limited to the 165,000 to 219,000 hectares estimated by the Indonesian government. ${ }^{176}$

Comment: Lovejoy does not accurately reflect what Lomborg wrote. ${ }^{177}$

\section{Supposed Fact Error}

Allegation: "Lomborg confuses forests and tree plantations" in considering how much forest is left. ${ }^{178}$

Comment: Lomborg's book explicitly recognizes the distinction. ${ }^{179}$

\section{Framing the Facts Inappropriately}

Allegation: Lomborg implies that the only value of forests is harvestable trees. ${ }^{180}$

171. See http://www.greenspirit.com/lomborg (last visited Oct. 15, 2002).

172. Lovejoy, supra note 38, at 70-71.

173. See http://www.greenspirit.com/lomborg (Rennie points out that this group issued a subsequent report qualifying this conclusion).

174. Lovejoy, supra note 38 , at 71 .

175. LomBorG, supra note 4 , at 111.

176. Lovejoy, supra note 38 , at 71 .

177. LomвоRG, supra note 4 , at 111 .

178. Lovejoy, supra note 38 , at 71.

179. LомвокG, supra note 4, at 111.

180. Lovejoy, supra note 38 , at 71 . 
Comment: This inaccurately represents Lomborg's position. ${ }^{181}$

\section{Framing the Facts Inappropriately}

Allegation: Lomborg quotes selectively. "In trying to show that it is impossible to establish the extinction rate, he states: "Colinvaux admits in Scientific American that the rate is "incalculabl[e]," . . . [w] hy not show that Colinvaux thought the number [was] large?"182

Comment: In the passage in question, Lomborg was discussing whether the extinction models are empirically grounded. ${ }^{183}$ The passage he quoted from Colinvaux was apt to that discussion. The passage that Lovejoy wants quoted was not. In any event, the point of that passage - that the number of species lost is large - is accepted by Lomborg. ${ }^{184}$

\section{Personal Attack}

Allegation: Lovejoy "sought to track references from the text to the footnotes to the bibliography to find but a mirage in the desert." 185

Comment: Lomborg's response: "Without references, this is an impossible critique to deal with - of course Lovejoy could have attempted to contact me (Scientific American did so on Holdren's catalyzing/electrolyzing water)."186

\section{Personal Attack}

Allegation: Lomborg is "ignorant of how environmental science proceeds." "The point is that things improve because of the efforts of environmentalists to flag a particular problem." 187

Comment: Lomborg's book acknowledges that environmentalists have helped to bring about improvements, but argues that other forces have been at work too. ${ }^{188}$

\footnotetext{
181. LомвоRG, supra note 4, at 115-16.

182. Lovejoy, supra note 38 , at 71.

183. LомвORG, supra note 4 , at 254.

184. See http://www.lomborg.com/files/Microsoft\%20Word\%20-\%20Reply\%20 to\%20Nature.pdf (last visited Nov. 5, 2002).

185. Lovejoy, supra note 38 , at 71.

186. See http://www.lomborg.com/files/Microsoft\%20Word\%20-\%20Reply\%20 to\%20Nature.pdf (last visited Nov. 5, 2002).

187. Lovejoy, supra note 38 , at 71.

188. LOMBORG, supra note 4 , at $169-70$.
} 
Stuart Pimm \& Jeff Harvey, No Need to Worry About the Future, NATURE, Nov, 2000.

\section{Personal Attack}

Allegation: "It is a mass of poorly digested material, deeply flawed in its selection of examples and analysis." 189

Comment: No specifics here.

\section{Personal Attack}

Allegation: The environmental litany Lomborg attacks comes from "quotes, news magazines, and a book by two science-fiction writers, but not scientists directly. No external references support the ensuing paragraphs justifying that 'things are getting better." 190

Comment: As noted in the body of this article, media sources are appropriate in establishing what the public hears and Lomborg's critics cite many of the same secondary sources that he relies upon. ${ }^{191}$

\section{Supposed Fact Error}

Allegation: "Lomborg writes that 'Scientific luminaries such as Harvard biologist E.O. Wilson and Stanford biologist Paul Ehrlich are the enthusiastic supporters of an ambitious plan . . . to move the entire population of the US . . p people would live in small enclosed city islands.' The reference is directly attributable to neither Wilson nor Ehrlich."192 Comment: The reference is to an article in Science. ${ }^{193}$

\section{Framing the Facts Inappropriately}

Allegation: In discussing poverty and starvation, Lomborg uses relative numbers, not absolutes. ${ }^{194}$

Comment: The book deals explicitly with the question of the morality of discussing these topics in terms of relative or absolute numbers. ${ }^{195}$

189. Pimm \& Harvey, supra note 37 , at 149.

190. Id.

191. See infra pp. 581-85.

192. Stuart Pimm \& Jeff Harvey, No Need to Worry About the Future, Nature, Nov. 2001 , at 149 .

193. See http://www.lomborg.com/files/Microsoft\%20Word\%20-\%20Reply\%20 to \%20Nature.pdf (last visited Nov. 5, 2002).

194. Pimm \& Harvey, supra note 37, at 149.

195. LомвоRG, supra note 4 , at 64 . 


\section{Framing the Facts Inappropriately}

Allegation: Lomborg is like a Holocaust denier in coming up with .07\% over 50 years extinction rate because he fails to consider the extinctions that we have not discovered. ${ }^{196}$

Comment: He does consider the fact that many extinctions go undiscovered. ${ }^{197}$ In addition, John Rennie acknowledged in his response to Lomborg's rebuttal that the $.07 \%$ figure is roughly "the figure that most environmental biologists currently tend to favor - including Lovejoy." 198

\section{Supposed Fact Error}

Allegation: "Concerning forest losses: 'his flawed examples are unoriginal . . [where] eastern forests were reduced ... this resulted in the extinction of only one forest bird.' The correct percentage [of forest lose] is close to $50 \%$, and the number of extinctions four, plus two seriously wounded. Those extinctions constitute $15 \%$ of the bird species found only within the region." 199

Comment: Lomborg's figures come from a report from the World Conservation Union. ${ }^{200}$

\section{Personal Attack}

Allegation: Cambridge University Press should not have published "a hastily prepared book on complex scientific issues which disagrees with the broad scientific peer reviewed publications."201

Comment: No specifies here.

\section{Michael Grubb, Relying on Manna from Heaven?, SCIENCE,} Nov. 9, 2001.

\section{No Longer Espoused}

Allegation: Lomborg portrays his book as a rebuttal to the "Environmental Litany" but focuses "on barely a dozen veterans of the environmental movement . . [b]y exposing their inadequacies, he implies that the whole panoply of environmental concerns is misguided." Instead, "eminent scientists who have offered more nuanced views, except

196. Pimm \& Harvey, supra note 37, at 149.

197. LOMBORG, supra note 4, at 249-57.

198. Rennie, supra note 56.

199. Pimm \& Harvey, supra note 37 , at 150.

200. See http://www.lomborg.com/files/Microsoft\%20Word\%20-\%20Reply\%20 to\%20Nature.pdf (last visited Nov. 5, 2002).

201. Pimm \& Harvey, supra note 37 , at 150. 
where they can be cited in support of the author's sweeping counterLitany," are "sparse."202

Comment: Lomborg's target is the message the public receives. ${ }^{203}$

\section{Personal Attack}

Allegation: Generally Lomborg occasionally "mined" key reviews by groups such as the Organization for Economic Cooperation and Development, the United Nations Environment Programme, the World Bank, and the WRI, "but their analyses ... get little recognition." Specifically, the European Union's official assessment "is not even in the reference list."204

Comment: It is true that Lomborg relies heavily on reports from other sources and is open about this. The EU's official Assessment is in the reference list. ${ }^{205}$

\section{Framing the Facts Inappropriately}

Allegation: Lomborg's most egregious error is the "stunning lack of attention to cause and effect." Lomborg casually dismisses the role legislation has played in improving the environment. This is especially prevalent in his discussion of London's air pollution. Lomborg, in a single paragraph, states that air pollution's decline "has been due to a change in infrastructure and fuel use and only slightly, if at all, connected to environmental worries expressed in concrete policy changes." 206

Comment: Lomborg's response: this issue is not dealt with in only one paragraph. ${ }^{207}$ The air pollution chapter cites "several studies that have found little or no effect of regulation." In addition, London's decline in air pollution after 1956 and the role that legislation may or may not have played is discussed specifically. "The analysis show that "while pollution, has, of course, fallen, the difference between the rate of fall before and after 1956, or the difference between cities that did or did not have pollution plans, is not discernible.' Plus, Lomborg does not say that environmental protection is not necessary. The introductory chapter gets to the heart of this very issue. "Pointing out that our most

202. Grubb, supra note 55, at 1285 .

203. See generally, LomвorG, supra note 4, at introduction.

204. Grubb, supra note 55, at 1285 .

205. LOMBORG, supra note 4, at 453.

206. Grubb, supra note 55, at 1286.

207. This response can be accessed from Lomborg's website at http:// www.lomborg.com/files/Microsoft\%20Word\%20-\%20Reply\%20to\%20Nature.pdf (last visited Nov. 5, 2002). 
publicized fears are incorrect does not mean that we should make no effort towards improving the environment. Far from it . . What this information should tell us is not to abandon action entirely, but to focus our attention on the most important problems and only to the extent warranted by the facts." 208

208. LomborG, supra note 4, at 5 . 